https://doi.org/10.15407/socium2021.02.095

UDC 316.354:355.1

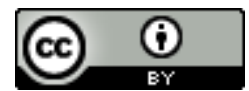

Creative Commons Attribution 4.0 International

Sokurianska L.H., Dr Habil (Sociology), Professor, The acting head of Sociology Department, V.N. Karazin Kharkiv National University, 6, Svoboda Sq., Kharkiv, 61022, Ukraine, email: sokuryanska@karazin.ua, ORCID iD: http://orcid.org/0000-0002-4097-952X,

Bataeva E.V., Dr Habil (Philosophy), Professor, Professor of Sociology and Humanities Department, Kharkiv University of Humanities "People's Ukrainian Academy", 27, Lermontovska Str., Kharkiv, 61000, Ukraine, email: bataevaekaterina72@yahoo.com, ORCID iD: http://orcid.org/0000-00024628-4817, Scopus Author ID: 57204186366,

Golikov A.S., Dr Habil (Sociology), Associate Professor, Associate Professor of Sociology Department, V.N. Karazin Kharkiv National University, 6, Svoboda Sq., Kharkiv, 61022, Ukraine, email: a.s.golikov@gmail.com,ORCID iD: http://orcid.org/0000-0002-6786-0393

\title{
SOCIAL SUPPORT FOR INTEGRATION PRACTICES OF UKRAINIAN VETERANS IN HIGHER EDUCATION
}

The article studies the features of social adaptation of veteran students in Ukrainian universities. The motivation of Ukrainian veterans to enter universities has been analysed. The main problems of their social adaptation to the university environment are revealed. Some results of five in-depth semistructured interviews with veteran students in Kharkiv universities are presented. In particular, the value foundations of veterans' motivation to enrol in universities have been identified. It is emphasised that veteran students perceive higher education as both terminal and instrumental value. Attention is focused on the fact that the value ambivalence influenced the educational motivation of veterans, for whom entering the university is an opportunity, on the one hand, to become an educated and self-realised person (terminal value) and, on the other hand, to have a good salary, make a career, take a higher status position in society (instrumental value). The positive influence of the military experience of veterans on their educational practices has been revealed. The opinion of most respondents is given regarding the fact that the army has taught them discipline, punctuality, which made them more self-confident. It is concluded that military experience contributes to developing some metacognitive learning skills in veterans, such as discipline and punctuality. The problems of academic integration of veteran students are considered. It is emphasised that veteran students do not experience difficulties in communication with other students and teachers and are not inclined to segregate from them. At the same time, there is little involvement of Ukrainian veterans in the university environment, which can be optimized in terms of social support for veterans in Ukrainian higher education. The author's model of social support for student veterans in Ukrainian universities is presented.

Keywords: veteran students, integration, veteran-friendly university environment, motivation for entering a university, terminal and instrumental values.

Сокурянська Л.Г., д-р сочіол. наук, проф., в. о. завідувача кафедри соціологї Харківського національного університету імені В.Н. Каразіна, пл. Свободи, 6, Харків, 61022, Україна, етаil: sokuryanska@karazin.ua, ORCID iD: http://orcid.org/0000-0002-4097-952X,

Батаєва К.В., д-р філос. наук, проф., професор кафедри соиіології та гуманітарних дисиипліп Харківського гуманітарного університету "Народна украӥнська академія", вул. Лермонтовська, 27, Харків, 61000, Україна, email: bataevaekaterina72@yahoo.com, ORCID iD: http://orcid.org/0000-0002-4628-4817, Scopus Author ID: 57204186366,

(C) Sokurianska L.H., Bataeva E.V., Golikov A.S., 2021

ISSN 1681-116X. Ukrainian Society, 2021, № 2 (77): 95-106 
Sokurianska L.H., Bataeva E.V., Golikov A.S.

Голіков О.С., д-р соціол. наук, доц., дочент кафедри соціології Харківського національного університету імені В.Н. Каразіна, пл. Свободи, 6, Харків, 61022, Україна, етаіl: a.s.golikov@gmail.com, ORCID iD: http://orcid.org/0000-0002-6786-0393

\section{СОЦАЛЬНА ПІДТРИМКА ІНТЕГРАЦІЙНИХ ПРАКТИК УКРАЇНСЬКИХ ВЕТЕРАНІВ У ЗАКЛАДАХ ВИЩОЇ ОСВІТИ}

Статтю присвячено дослідженню особливостей соиіальної адаптаиії студентів-ветеранів в українських університетах. Проаналізовано мотивачію украӥнських ветеранів до вступу до закладів вищої освіти. Виявлено основні проблеми їх соціальної адаптації до університетського середовища. Наведено деякі результати п'яти глибинних напівструктурованих інтерв'ю, проведених зі студентами-ветеранами, які навчаються в державних закладах вищої освіти Харкова. Зокрема, визначено иіннісні засади мотивації ветеранів до вступу до вітчизняних закладів вищої освіти; зазначено, щчо вищу освіту студенти-ветерани сприймають $i$ як термінальну, $і$ як інструментальну цінність. Підкреслено, щуо ціннісна амбівалентність вплинула на освітню мотивацію ветеранів, для яких вступ до університету $\epsilon$ можливістю, з одного боку, стати освіченою та самореалізованою людиною (термінальна цінність), з іншого, -мати гарну заробітну плату, побудувати кар'єру, зайняти більш високе статусне положення в суспільстві (інструментальна иінність). Виявлено позитивний вплив мілітарного досвіду ветеранів на їхні навчальні практики. Наведено думку більшості респондентів стосовно того, що армія привчила їх до дисципліни, пунктуальності, зробила більш впевненими в собі. Сформульовано висновок, щуо мілітарний досвід сприяє розвитку у ветеранів деяких метакогнітивних навичок навчання, таких як дисиипліна та пунктуальність. Розглянуто проблеми академічної інтеграції студентів-ветеранів. Підкреслено, щзо результати дослідження свідчать про те, щуо студенти-ветерани не відчувають труднощів у комунікації з іншими студентами та викладачами $і$ не схильні до сегрегації від них. Водночас констатовано незначну залученість украӥнських ветеранів до університетського середовища, що може бути оптимізовано за умов соиіальної підтримки ветеранів у закладах вищої освіти України. Запропоновано авторську модель сочіальної підтримки студентів-ветеранів в університетах Украӥни.

Ключові слова: студенти-ветерани, інтеграчія, дружнє до ветеранів університетське середовище, мотивація вступу до ЗВО, термінальні та інструментальні иінності.

The post-military transition of service(wo)men from the army to the civilian field might be complicated due to the socio-cultural discrepancy between a highly structured and regulated military environment and a weakly regulated civil field. This discrepancy might also manifest itself in the academic environment in which service(wo)men are faced with the need to independently solve problems of social adaptation to university life, establish contacts with teachers and other students, carry out educational tasks while in the army the responsibility for fulfilling various life tasks is put on commanders. As N. Schlossberg emphasizes, the more significant the difference between pre-transition and post-transition conditions of life of a social actor, the more difficult it for him/her is to adapt to a new sociocultural environment [1]. To make the post-military transition of veterans to a university easier and painless, it is necessary to provide them with social support at interpersonal and institutional levels. Social facilitation of post-military transition of veterans to higher education and assistance in academic advancement has been actualized in a modern information society where higher education is an essential condition for making a prosperous 
professional career and ensuring a high level of social and financial well-being. We will use a modified definition of the term "veteran student" by D. Vacchi ${ }^{1}$ : "A veteran student is a student who is a current or former member of the Active-Duty Military, the National Guard, Reserves or other military formations and law enforcement agencies who could take part in combat actions on the territory of their own or other states" [3, p. 168].

Many researchers include veteran students into the category of non-traditional students, which are characterized by a significant age difference concerning other students; entry to a university with an inevitable time delay (several years after graduation); the presence of dependents (a spouse, parents, children) who must be maintained; combining work with learning and, as a result, partial attendance of courses. Non-traditional students, as a rule, have multiple problems with social adaptation to the academic environment, with performance (since their school skills have not been used for a long time), with establishing contacts with other students (who entered university immediately after graduation, are much younger, have better preparation and less life experience). Veteran students are a special kind of non-traditional students who, in addition to the listed features, have a military (often traumatic) experience and possible disabilities and/or psychological disorders [4-8].

Integrating veterans into the university environment has been studied in Western sociology, psychology, and pedagogy. Much attention has been paid to developing the concept of a 'veteran-friendly' 2 university environment with 'sensitivity' to their problems, aimed at developing and implementing various programs to optimize the educational process and improve the learning skills of veteran students [9; 10]. Persky and Oliver (2010) stress that "veteran-friendly" universities oriented to the needs of veterans and publicly transmitting the idea of their social support are attractive to veteran students since such universities can help improving veterans' academic performance and reduce the risk of their premature departure [11, p. 117]. In many Ukrainian universities, the programs of sensitivity and friendliness towards veteran students to provide them with a comfortable learning environment have not been developed yet. Perhaps this is one of the reasons that only $0,8 \%$ of veterans of military operations in the Donbas (Eastern Ukrainian region, where the armed conflict has been ongoing since 2014) study at Ukrainian universities now [6, p. 110]. Therefore, there is a need to study the conditions of veterans' learning in Ukrainian universities, identify problems associated with their academic adaptation and develop the methodology of social support for veteran students.

The research object is the social integration of veteran students in Ukrainian universities. The purpose of the study is 1) to analyse the Ukrainian veterans' motivation of entering universities; 2) to identify the basic problems of their social adaptation to the university environment; 3 ) to provide a methodology of social support for veteran students in

\footnotetext{
1 "A student veteran is a student who is a current or former member of the Active-Duty Military, the National Guard, or Reserves regardless of deployment status, combat experience or legal veteran status" [2, p. 17].

2 "The term veteran-friendly refers to marked efforts made by individual campuses to identify and remove barriers to the educational goals of veterans, to create smooth transitions from military life to college life, and to provide information about available benefits and services" [9, p. 45].
} 
Ukrainian universities. The research method is the in-depth semi-structured interview; interviews have been conducted face-to-face with five veteran students studying in state universities of Kharkiv, namely V.N. Karazin Kharkiv National University, Kharkiv Petro Vasylenko National Technical University of Agriculture, Kharkiv National University of Internal Affairs, H.S. Skovoroda Kharkiv National Pedagogical University, in March-April 2019. Five veteran students have been selected based on two criteria: 1) the status of a participant in combat operations in Donbas; 2) the fact of studying at a Ukrainian higher education institution. The survey sample included only male students since there were no female veteran students at the selected universities. An electronic recording of the interviews has been performed with subsequent text transcription; to increase the reliability of research results, the triangulation method has been used (three researchers have analysed the interview texts); the average interview duration was 45 minutes. Information about interview participants is presented in Table 1.

Table 1

Participants in the study "Ukrainian veterans in universities"

\begin{tabular}{|c|c|c|c|c|c|}
\hline Participants & Sex & Age & $\begin{array}{l}\text { University, faculty, year of study, a } \\
\text { form of learning }\end{array}$ & $\begin{array}{l}\text { Number of } \\
\text { years/months } \\
\text { spent in the } \\
\text { combat zone }\end{array}$ & $\begin{array}{l}\text { Number of years from } \\
\text { graduation from school/college } \\
\text { to entering university }\end{array}$ \\
\hline Participant 1 & M. & 27 & $\begin{array}{l}\text { Kharkiv Petro Vasylenko National } \\
\text { Technical University of } \\
\text { Agriculture, Faculty of Law, the } \\
\text { second year of study, distance } \\
\text { learning }\end{array}$ & $\begin{array}{l}1 \text { year } 8 \\
\text { months }\end{array}$ & 7 years \\
\hline Participant 2 & M. & 23 & $\begin{array}{l}\text { H.S. Skovoroda Kharkiv National } \\
\text { Pedagogical University, Faculty } \\
\text { of Law, the third year of study, } \\
\text { distance learning }\end{array}$ & 4 months & 3 years \\
\hline Participant 3 & M. & 24 & $\begin{array}{l}\text { V.N. Karazin Kharkiv National } \\
\text { University, Physics and } \\
\text { Technology Faculty, the first year } \\
\text { of magistracy, full-time education }\end{array}$ & 1 year & $\begin{array}{l}\text { He entered immediately } \\
\text { after graduation, but after } \\
\text { the third year of study at } \\
\text { the university, he joined } \\
\text { the army for three years }\end{array}$ \\
\hline Participant 4 & M. & 32 & $\begin{array}{l}\text { Kharkiv National University of } \\
\text { Internal Affairs, Faculty of Law, } \\
\text { the fourth year of study, distance } \\
\text { learning }\end{array}$ & 4 years & 10 years \\
\hline Participant 5 & M. & 36 & $\begin{array}{l}\text { Kharkiv National University of } \\
\text { Internal Affairs, Faculty of Law, } \\
\text { the fifth year of study, distance } \\
\text { learning }\end{array}$ & 2,5 years & 12 years \\
\hline
\end{tabular}

T. Woodruf, R. Kelty, D. Segal, L. Zinger, A. Cohen, D. DiRamio, K. Jarvis, D. Molina believe that one of the main reasons for voluntary enrolment in the US army is the desire to 
earn money for entering a college or university ${ }^{3}$, and to get benefits for free education in universities $[4 ; 8 ; 12 ; 13]$. This factor can have a severe impact on the social actors' decision to enrol in the army. In Ukraine, amendments to the law "On the Status of War Veterans and Guarantees of their Social Protection" were introduced in 2015 and 2018, providing free training and social scholarships to veteran students.

Hunter-Johnson (2018) stresses that the main reasons for veterans' entering higher education are self-improvement, advanced training, increased career growth opportunities, and the possibility of obtaining a post with higher requirements for knowledge and skills, and, accordingly, with a higher salary [5, p. 68]. Perna and Titus (2005), Molina (2015) study the influence of a veteran's academic, cultural, and social capital on their attitude to entering a university $[13 ; 14]$. They reveal that good performance in school and knowledge of mathematics positively affect veterans' desire to earn a higher education. Parents' cultural and social capital (linguistic and cultural competencies, higher education diplomas, and social ties with status social actors) also positively correlates with veterans' academic careers. Molina (2015) has analysed what is the impact of such an aspect of veterans' social capital as the presence of friends who enrolled (or intend to enrol) in universities on their decision to get a diploma. Respondents who had "none" or "few" friends planning to enrol in universities were more likely to choose a two-year college than those who had "majority" or "all" friends enrolled in higher education. The choice of university career was also related to the urban or rural context of veteran graduation/residence: it was found that veterans who graduated from urban rather than rural schools were more likely to enter universities [13].

It is also necessary to consider demotivating factors that might hinder veterans' entering to universities: a large gap between graduation from school and entry to a university (in our study, this gap was from 3 to 12 years (see Table 1)); financial independence; full-time employment; the presence of dependents to take care of; single parenthood; lack of a school diploma [7, p. 776]. According to D. Cunningham's research, most veteran students are over 23 years old, and $33 \%$ are married parents [15, p. 17]. Family responsibilities and the need to work for the maintenance of their family can distract veterans from learning and cause nonentering/departure from a university.

Results. Let us analyse the study results "Ukrainian veterans at the university", divided into two blocks: motivation for entering a university; problems related to academic integration (problems with studies and interaction with other students and teachers).

An analysis of answers of our respondents to the question of why they decided to get higher education has shown that the academic motivation of this specific group of students is practically the same as the motivation of other students. According to the results of numerous studies [16-18], students of the first two decades of the 21st century perceive higher education as both terminal (the desire to become an educated and self-realized person) and instrumental (the wish to have a good salary, make a career, take a higher status position in society) values. Moreover, such an ambivalent attitude towards higher education may be

\footnotetext{
${ }^{3}$ According to a study by Woodruff, Kelty \& Segal (2006), 61\% of military personnel $(\mathrm{n}=257)$ state that one of the main reasons for enlistment in the army was the need to earn money for entering a university [12, p. 359].
} 
inherent not for different respondents but the same ones. We have observed the same trend in interviews with student veterans of the armed conflict in Donbas. According to Participant 1, higher education is necessary to develop himself (the terminal value), to do business (the instrumental value). Participant 5 answered: "I always wanted to have ... a higher education for self-affirmation and to become an officer". Reflecting on why he needs a higher education (for career, self-realization, or wealth), the same respondent emphasized: "Self-realization entails a career and wealthy at the same time". As one can see, the value ambivalence is evident.

In some interviews, the instrumental component of getting higher education has manifested itself even more vividly:

"Higher education is necessary to ... continue career making. You will not receive an officer rank without a higher education ... Higher education affects a person. If a person has a business but has no higher education, then there is no trust in him/her. And when I know that a person has graduated from a good university, my opinion about him/her is good", (Participant 2).

As for the trend that has recently become widespread (we mean such an attitude towards higher education as a means of obtaining a diploma), we have not found it in the interviews. On the one hand, this can be explained by a small number of respondents. On the other hand, this may be since all the respondents have clearly expressed their professional orientation. The majority of respondents (four participants) receive education in the field of law sciences, which corresponds both to their educational interests and (directly or indirectly) to army experience or activities that they are or were engaged in (for example, serving in the battalion of special police). One of the respondents (Participant 3) continued his education at the Faculty of Physics and Technology of Karazin Kharkiv National University. In the fourth year of education, he, for some reason, left his studies and went to the army, but after returning from the army, he decided to continue his learning. This respondent perceives a higher education as a terminal value: "Knowledge is a value, and therefore, a diploma is valued".

The respondents explained the choice of a particular university both with professional interest and a relatively low tuition price. None of the respondents regrets that he entered the university (or continued getting an education) and is not going to stop studying:

"If there is an opportunity to develop, if there is an opportunity to get something, to learn something, then why drop out of the university?" (Participant 1).

The respondents highly evaluate the opportunity to learn, at least, at the level of declaration and the cognitive component of their student identity. In addition, some colleagues of our respondents also decided to study at universities. For example, Participant 1 has two such colleagues, Participant 5 has about thirty such mates, Participant 2 answered that many military fellows are students now. As our respondents noted, most of their colleagues, having been demobilized, go to work, especially since many of them are over 30 years old. For this reason, almost all respondents do not want to agitate their friends to enter a university. As for the attitude of respondents' parents to their decision on entering a university, it was unambiguously positive. It applies both to relatives with higher education and those who do not have it. It confirms the existence of two sources of reproduction of a cohort of specialists with higher education: firstly, highly educated families, where education is perceived as a terminal value, and, secondly, 
families with a low educational level, where education is a factor in increasing material wellbeing and social status (as an instrumental value).

The attitude of veteran students towards their entering the universities is quite ordinary; they do not perceive it as an outstanding event. Nevertheless, some of them believe that after entering the university, their lives became more meaningful:

"Yes, I think so, because steps are already being taken ... to self-development. And that's good ... I feel like a more purposeful person" (Participant 1).

Answering the question of whether military experience helps to achieve better academic results, the majority of respondents noted that the army accustomed them to discipline (Participant 5), punctuality, made them more self-confident (Participant 1), helped to get rid of the fear that they had, for example, before the exam earlier (Participant 3). At the same time, Participant 3 says that he enjoys "the advantages of a civilian life" when one can "get enough sleep for all those hours that one hasn't slept in the army, one can be late somewhere and is not punished for it". Assessing the role of army experience in his life, Participant 2 noted that "the army develops logical thinking; attitudes to life change completely".

Almost all of the respondents have noted that they have no problems with their studies. If they arose, for example, with the perception of the content of a particular course, then, as Participant 1 answered, "there were people who helped me, those were some students with whom I studied". The four students interviewed continue their service, including periodically participating in combat actions in the Donbas, which "creates some problems, in particular, being late for the session" (Participant 4).

Let us consider problems related to the academic integration of veteran students. As it turned out, veteran students do not feel their "isolation" from classmates. Their answers do not demonstrate any particular problems associated with such communication. It may have been facilitated by the fact that respondents did not feel (at least, declaratively) lagging behind other students. What could be the reasons for this - whether teachers' specific attitudes to them, their level of preparation, or the requirements of the modern education system - this is another question.

It should be noted that they did not feel the discomfort of this lagging. Participant 3 even mentioned that he had gained some advantage due to the army biography stage: the attitude of teachers to him has changed as to a person more socially experienced than ordinary students. This is why the configuration of respondents' integration has almost no appeal to civilian students' moral and ethical obligations to veteran students. And even aggravating the question ("Did you feel angry because other students did not fight?") did not allow us to say that respondents have hidden something; they indicated that they had never experienced negative emotions concerning other students.

In general, the socio-emotional background of our respondents in higher education can be defined as positive, without traumatic or frustrating factors. However, there is a detail that forces us to problematize this supposedly optimistic situation. These are micro-practices of friendship described by respondents themselves. They talked about friendly relationships with their classmates and military fellows and the lack of alienation from them. However, some contradiction arises: at the declarative level, respondents manifest a need for friendship, a willingness to communicate, but no respondent said that he had true friends 
among classmates. There are several explanations for this. Firstly, one can assume that the daily military routine sets specific requirements for friendly communication and practices, making it difficult for veterans to adapt to civilian environments. Secondly, it is possible to assume that the "friendship space" of respondents who are generally more mature and adult than the ordinary students is already occupied at the time of integration into educational institutions. Thirdly, one can look for causes in the generational difference (although respondents themselves stated that it is not critical) or a difference in social experience. Fourthly, when interpreting the data, it should be taken into account that most respondents are part-time students. This also somewhat limits informal practices and their opportunities for communication with classmates and closer friendships with them. In addition, it should be noted that all the respondents are employed, some of them still serve in the military, which affects their relationship with classmates.

According to our research, the attention from teachers and students towards the military past of respondents is practically insignificant: almost no one showed interest in their military experience. Moreover, respondents themselves do not demonstrate any interest in communication on such a topic: "I have never raised this topic" (Participant 2). The respect, which could have been hypothetically anticipated as a possible consequence of the previous military experience of the respondents, was not mentioned in interviews. As for academic practices, veteran students noted that "everything is going easy" except for "inconsistency of lecture content". However, they implicitly deny the need for tutors, believing that they just need more time for learning and that social and material conditions providing this time are more necessary than tutors' assistance. Therefore, one can assume that Ukrainian veteran students have sufficient social skills to solve problems they face in universities by themselves.

However, although Ukrainian veterans are optimistic about their position in Ukrainian universities, there is a need to develop social support for veteran students since, as mentioned above, only $0,8 \%$ of Ukrainian veterans decided to get a higher education diploma after returning from the army. Post-military transition through higher education can significantly contribute to the social adaptation of veterans. For Ukrainian universities to become more attractive for veterans, it is necessary to develop and implement the model of social support for veteran students, considering Ukrainian socio-cultural conditions.

The social support model for Ukrainian veteran students. In modern sociology and pedagogy, great attention is paid to developing social projects to facilitate veteran students in their social adaptation to the academic environment. E. Campbell, L. Zinger, A. Cohen, K. Persky, D. Oliver, V. Beachboard, J. Beachboard, W. Li, S. Adkison $[8 ; 11 ; 19 ; 20]$ explore the benefits of a "cohort project" aimed at developing special courses for veterans and the creation of autonomous groups (or cohorts ${ }^{4}$ ) of veteran students. The advantages of such veteran cohorts are, firstly, their ideological connection with the phenomenon of a combat team, highly valued in military communities, in which veterans gain personal security and support in educational/life problems; secondly, their separation from groups of traditional students, with whom veterans might have communication

\footnotetext{
${ }^{4}$ Cohorts of veterans are communities of actors with similar life experiences and general sociocultural preferences that have been formed in the process of secondary socialization in the army.
} 
problems. For example, many American veterans emphasize that it is difficult for them to learn with other students who have not yet formed socially mature life positions, who have not the serious attitude to study and do not respect teachers, who are superficial in their life estimations $[7 ; 8 ; 11 ; 20]$.

In some studies, on the contrary, criticism of the cohort project for veterans is given since such a training format can conserve veterans' identification with military communities and slow down transforming military identity into civilian one, which can adversely affect their social adaptation and academic success. DiRamio \& Jarvis (2011), Francis \& Kraus (2012), M. Beachboard, W. Li, S. Adkison, I. Saltiel, C. Russo believe that the high level of solidarity of veteran students' cohort can have a negative effect such as self-isolation and perception of others (students, administration, teachers) as "aliens" $[4$, p. $42 ; 10$, p. $13 ; 18$, p. $856 ; 21$, p. 61$]$.

In American social projects for veteran students, great importance is given to creating resource centres for veterans, where they can meet for joint rest, solve everyday or learning problems, get necessary information about an academic career, tutoring sessions $[8 ; 10$, p. 12]. As D. Mackiewicz underlines, it is desirable to establish psychological counselling services at university centres for veterans to assist in treating post-traumatic stress disorder and its consequences, such as depression, anxiety, suicidal thoughts, problems with memory, and concentration [22]. To find out what problems with social integration the veteran students face, it is necessary to regularly monitor the general level of their adaptation using sociological and psychological methods [14].

Some programs of social support for veteran students emphasize the importance of establishing the post of "veteran counsellors" in universities [7], whose responsibility is to mentor veteran students, to help with settling in a dormitory, mastering training courses, making contacts with classmates, teachers, and university administration. It is believed that former military personnel who are well acquainted with the problems of veterans and can give them some practical advice on adapting to the university environment, can become the best consultants. Consultants (as well as teachers and students) should be well aware of the problems of post-military transition of veterans and peculiarities of interaction with them $[8 ; 11 ; 20]$. The non-acquaintance of teachers, students, and consultants about specifics of the behaviour/worldview of veterans, disrespectful attitude to their combat experience can cause distancing of veterans, and, at the worst, their departure from the university $[7 ; 8]$.

In our study, we found out the attitude of veteran students to the possibility of establishing resource centres for veterans in Ukrainian universities. Three interviewed student veterans critically accepted the idea of creating such centres in Ukrainian universities. For example, Participant 2 believes that the idea of creating a community of student veterans does not fully correspond to the mental characteristics of Ukrainians who do not like to separate from others and lock themselves in clubs by interests, do not want to advertise their problems:

"In Western countries, this [creation of centres] is possible, but it is unlikely for us, it is poorly perceived. ... I think that our society is not yet ready for this. Individual meetings [with a psychologist] are needed, but only in private". 
Participant 3 was also sceptical of the possibility of creating such centres in Ukrainian universities. According to him, in Ukraine, many different organizations deal with the problems of veterans (volunteer and medical services, the Ministry of Veterans), so the creation of additional services in universities can contribute to the development of bureaucracy. In addition, in his opinion, Ukrainians are used to distrusting various services and do not believe that they can be helped there; for this reason, university centres of veterans may remain needless:

"All these services will initially be doomed to failure because no one will go there. To get together and complain about how hard life is and how we all are not understood... (laughs). Well, it's wretched..."

One of the veteran students (Participant 5) preferred online communities rather than a resource centre at the university. Only Participant 1 positively appreciated the idea of creating resource centres for veterans in universities. However, he emphasized that these centres can be helpful only for students who are studying full-time and who need psychological help: "I believe that when a person fails to study, he needs help. The centres could help in this".

Thus, on the one hand, the respondents differentiate the target group of social services (for example, for "full-time" and "part-time" students, who, in their view, require different approaches to psychological adaptation; note that they considered full-time students as a riskier group). On the other hand, the respondents pointed to the irrelevance of the Ukrainian medical culture to the needs and requirements of veteran students. Finally, they allowed such an opportunity, although they did not demonstrate particular enthusiasm for such an idea. In such reactions, one can also see a reluctance to create special structures that would separate this group of students from ordinary ones. In this context, it can be hypothesized that such unique structures can only impair and complicate veteran students' (re)integration into Ukrainian society.

Evaluating the problem of implementing a cohort study program in Ukrainian universities, one should take into account some objections: firstly, the number of veteran students in Ukrainian universities is low, they often study at different faculties and different courses, so combining them into cohort groups can be ineffective or even impossible; secondly, all interviewed veteran students emphasized the presence of comradely, warm relations with traditional students in learning groups, which gives evidence of the irrelevance of the topic of mutual alienation of veterans and traditional students in Ukrainian society. For example, Participant 3 says:

"The front-line brotherhood ends after the demobilization because everyone goes home to different regions. Each has his own life - someone works somewhere ... you can't keep in touch with everyone. I communicate with classmates at the university even more than with army comrades. There were no conflicts, exclusion, or other problems with classmates. We immediately established normal and working relations".

Thus, it can be assumed that cohort training of veterans in Ukrainian universities is currently not possible or necessary. 
As a result of studying special literature and analysing results of our research, the project of social support for veterans in Ukrainian universities was developed, which includes the following recommendations: 1) establishment of a post of educational consultant for veterans; 2) conducting informational work with teachers, administration and students of the university to form sensitivity to learning features of student veterans; 3) organization of preparatory (tutoring) courses for veterans to facilitate their transition to the academic field; 4) development of distance learning courses for veteran students; 5) creation of online information pages for veterans on university website; 6) engagement of veteran students into various educational and social projects to form academic loyalty.

Conclusions. The implementation of the project for social support of veterans in Ukrainian universities presented in the article can contribute to more active engagement of veterans in the academic environment and the creation of comfortable learning conditions.

The results of our study have revealed several findings:

1. The veteran students have demonstrated a value-ambivalent attitude towards higher education, which they perceive as terminal and instrumental values. The value ambivalence has influenced the educational motivation of veterans for whom entering a university was an opportunity to become an educated and self-realized person (the terminal value) and have a good salary, make a career, take a higher status position in society (the instrumental value).

2. Social integration of veteran students into the academic environment might be facilitated by learning in regular rather than cohort groups. The support project for student veterans should be based on the principles of inclusion both at the discourse level and at the level of practices; this is consistent with the experience of the most successful models of (re)integration and inclusion of different social groups.

3. Entering veterans to a university can facilitate and accelerate their transition from military to civilian fields. The development of curriculums for veterans focused on mastering the chosen speciality, studying psychological aspects of academic and business communication can contribute to the successful post-military transition. An essential aspect of veteran loyalty programs is the development of online support services on university websites. Their purpose is to provide veteran students with up-to-date information about career opportunities in the academic environment.

In the future, it is necessary to conduct additional studies using not only qualitative but also quantitative methods to clarify and develop a project to facilitate the transition of veteran students from military to civilian fields.

\section{References}

1. Schlossberg, N.K. (1981). A Model for Analyzing Human Adaptation to Transition. The Counseling Psychologist, 9, 2. https://doi.org/10.1177/001100008100900202

2. Vacchi, D. (2012). Considering Student Veterans on the Twenty-first Century College Campus. About Campus, 17 (2), 15-21. https://doi.org/10.1002/abc.21075

3. Sokurianska, L., Bataeva, E., Bakirov, V. (2019). Ukrainian veterans in higher education: military identity and educational practices. The Ideology and Politics Journal, 2 (13), 16-33. URL: https://www.ideopol.org/wp-content/uploads/2019/12/__ENG.\%201.9.\%20Sokurianska\%20et\%20al\%20FIN.pdf 
Sokurianska L.H., Bataeva E.V., Golikov A.S.

4. DiRamio, D., Jarvis, K. (2011). Veterans in Higher Education: when Johnny and Jane Come Marching to Campus. ASHE Higher Education Report, 37 (3), 1-144.

5. Hunter-Johnson, Y. (2018). Promoting Veterans in Higher Education: Motivation and Adjustments to Their Learning Environments. International Research Journal of Curriculum and Pedagogy, 4 (1), 66-79.

6. Mramornova, O., Kharchenko, O. (2017). Employment Problems of Veterans of Anti-Terrorist Operation (ATO) in Eastern Ukraine. Humanizację Pracy, 1 (287), 107-123.

7. Wheeler, H.A. (2012). Veterans' transitions to community college: a case study. Community College Journal of Research and Practice, 36 (10): 775-792. https://doi.org/10.1080/ 10668926.2012.679457

8. Zinger, L., Cohen, A. (2010). Veterans Returning from War into the Classroom: How Can Colleges Be Better Prepared to Meet Their Needs. Contemporary Issues in Education Research (CIER), 3 (1), 39-52. https://doi.org/10.19030/cier.v3i1.160

9. Lokken, J.M., Pfeffer, D., McCauley, J., Strong, C. (2009). A Statewide Approach to Creating Veteran-Friendly Campuses. New Directions for Student Services, 12, 45-54. https://doi.org/10.1002/ss.315

10. Francis, L.C., Kraus, A. (2012). Developing a Student Veteran Center: The Confluence of Academic and Military Cultures. About Campus, 17 (4), 11-14. https://doi.org/10.1002/abc.21087

11. Persky, K.R., Oliver, D.E. (2010). Veterans Coming Home to the Community College: Linking Research to Practice. Community College Journal of Research and Practice, 35 (1-2), 111-120. https://doi.org/10.1080/10668926.2011.525184

12. Woodruff, T., Kelty, R., Segal, D.R. (2006). Propensity to Serve and Motivation to Enlist Among American Combat Soldiers. Armed Forces and Society, 32 (3), 353-366. https://doi.org/ $10.1177 / 0095327 \times 05283040$

13. Molina, D. (2015). Post-9/11 Military Veterans and Higher Education: Factors Associated with College Enrollment and Choice. University of California.

14. Perna, L.W., Titus, M.A. (2005). The Relationship Between Parental Involvement as Social Capital and College Enrollment: An Examination of Racial/Ethnic Group Differences. Journal of Higher Education, 76 (5), 485-518.

15. Cunningham, J. (2012). Veteran's Post-Secondary Education: Keeping the Promise to Those Who Serve. The Hinckley Journal of Politics, 13, 14-20.

16. Arbenina, V., Sokurianska, L. (2012). State of Modern Students' Educational Practices as a Socio-Cultural Barrier of Modernization of Higher Education in Ukraine. Ukrainian Sociological Journal, 1-2, 27-47 [in Ukrainian]

17. Arbenina, V., Sokurianska, L. (Eds.) (2012). Ukrainian students in searching of identity. Kharkiv: V.N. Karasin Kharkiv National University [in Ukrainian]

18. Sokurianska, L. (2006). Students on the Way to Another Society: The Value Discourse of Transition. Kharkiv: V.N. Karasin Kharkiv National University [in Russian]

19. Beachboard, M.R., Beachboard, J.C., Li, W., Adkison, S.R. (2011). Cohorts and Relatedness: Self-determination Theory as an Explanation of How Learning Communities Affect Educational Outcomes. Research in Higher Education, 52, 853-874. https://doi.org/10.1007/s11162-011-9221-8

20. Campbell, E. (2016). Veteran Student Success: An Evaluation of Veteran Students' Perceptions of a Cohort Learning Model. Oregon State University. URL: https://ir.library.oregonstate.edu/ concern/graduate_thesis_or_dissertations/n009w6581

21. Saltiel, I.M., Russo, C.S. (2001). Cohort Programming and Learning: Improving Educational Experiences for Adult Learners. Malabar, FL: Krieger.

22. Mackiewicz, D.H. (2018). An Exploration of Student Veterans' Transitions from the Military to a Two-Year Community College and Their Perceptions of Support Services and Veteran Programs. Northeastern University. URL: https://repository.library.northeastern.edu/files/neu:cj82r877n

Received on 02.06.21 and updated on 14.06.21 